\title{
Minimising Insecticide Application in the Control of Insect Pests of Cowpea (Vigna Unguiculata (L) WALP) in Delta State, Nigeria
}

\author{
E. O. Egho (Corresponding author) \\ Department of Agronomy, Faculty of Agriculture \\ Asaba Campus, Delta State University \\ Asaba, Nigeria \\ E-mail: ebenezer.egho@yahoo.com \\ E. C. Enujeke \\ Department of Agronomy, Faculty of Agriculture \\ Asaba Campus, Delta State University \\ Asaba, Nigeria \\ Accepted: October 24, $2011 \quad$ Published: February 1, 2012 \\ URL: http://dx.doi.org/10.5539/sar.v1n1p87
}

Received: August 30, 2011

doi:10.5539/sar.v1n1p87

\begin{abstract}
Many commercial cowpea farmers control insect pests on cowpea with synthetic chemicals and may sometimes spray their farms during the growing season as many as 8 to 10 times. This leads to health hazards and environmental pollution. The present study was conducted to reduce the number of times, cypermethrin (conventional chemical) is applied before harvest and still, produce the expected cowpea grains. The experiments were carried out in two agro-ecological zones - Asaba and Abraka of Delta State during the late cropping season. The experiments consisted of 4 treatments - cowpea plots sprayed 4 times (at 7 days' intervals), cowpea plots sprayed 5 times (at 10 days' intervals), cowpea plots whose insect infestation were monitored before chemical application and control plots (without chemical treatment). Each treatment was replicated 3 times. The experiments were organised into a randomised complete block design (RCBD). The results indicated that cypermethrin controlled the major insect pests of cowpea. Second, grain yield was high at both locations; significant differences did not exist $(\mathrm{P}>0.05)$ in insect number and grain yield among the treatments. The study provides the evidence that (i) high cowpea grain yield is obtained at reduced number of chemical application of 4 or 5 times during the growing season (ii) Grain yield was significantly $(\mathrm{P}<0.05)$ higher at Abraka with1400.60kg $\mathrm{ha}^{-1}$ than Asaba (714.40 $\mathrm{kg} \mathrm{ha}^{-1}$ ) during the late cropping season.
\end{abstract}

Keywords: Late cropping, Cowpea, Insect pests, Cypermethrin, Grain yield, Asaba/Abraka

\section{Introduction}

One of the food crops that has become very popular in recent times in Africa, particularly Nigeria is the legume crop - Cowpea (Vigna unguiculata (L) Walp). It is intensively and widely grown in the humid and semi-arid regions of the world (Jackai et al., 2001). The main production belt in Nigeria is the drier Northern states - in the Sudan savannah region (Rachie, 1985). The cultivation, however spread lately to southern Nigeria and it is being cultivated successfully in the West and East (FOS, 1995; Emosairue et al., 2004).

The popularity of cowpea is due to its importance in the diet of man. It is a cheap source of plant protein (Alabi et al., 2003) since protein obtained from meat, fish and eggs have gone out of his reach. Appropriately, Aykroid and Doughty (1982) described cowpea as the poor man's meat. Besides, cowpea is rich in vitamins, minerals and fats and oils. In some African communities, it is consumed as vegetables (Duke, 1981). Other usefulness of cowpea is in fodder production (Job et al., 1983), fibre production (Rachie, 1983) and erosion control (Okigbo, 1978). 
Though highly valued and intensively grown, yields are generally poor in Africa at the farm level, hardly above $300 \mathrm{~kg} \mathrm{ha}^{-1}$ (Omongo et al., 1997). This is due to heavy decimation by a wide spectrum of insect pests, and attack by diseases while in the field (Taylor, 1964). The key insect pests of cowpea clearly identified as field pests are the cowpea aphid, Aphis craccivora Koch, the flower bud thrips, Megalurothrips sjostedti Tryb, the legume pod borer, Maruca vitrata Fab and a complex of pod sucking bugs which include Clavigralla tomentosicollis, Stal, $C$. shadabi Doll, Anoplocnemis curvipes Fab, Riptortus dentines Fab. (Jackai et al., 1988). Sixty to eighty percent (60-80\%) of grain losses due to their activities have been reported (Singh \& Allen, 1980; Jackai \& Daoust, 1986). For meaningful grain yield, control must be carried out (Suh et al., 1986) and the most reliable and effective control method is the application of synthetic chemicals and yield increase, several fold has been recorded (Jackai, 1993). Sometimes however, insecticides are excessively and unwisely applied (Omongo et al., 1997) leading to environmental pollution (Alabi et al., 2003), toxicity to mammals, destruction of beneficial organisms such as predators, parasites and parasitoids. Other problems associated with chemical usage are cost of insecticides and equipment (Afun et al., 1991). A growing awareness of the dangers of chemicals in pest control has resulted in the recommendation that chemical application should be minimized but not to be discarded (Stern, 1973) since such move would reduce crop productivity. Ecological approach to insect pests management in some parts of the world, particularly in African countries to reduce pesticide usage tends to receive the attention of farmers. Such approach include cultural control practices such as species diversification, manipulation of planting dates (Omoloye et al., 2000; Tobih et al., 2011; Tobih, 2011) intercropping (Olaniyan et al., 2001; Okonman \& Emosairue, 2005) use of crop varieties (Agbaje et al., 2002; Adamu et al., 2007), use of trap cropping, mulching (Ikeorgu \& Igwilo, 2002) and host evasion. With cultural control practices, several crops have been successfully protected (Jackai, 1983b). However, many cowpea farmers would prefer chemical usage to cultural approach and they apply insecticides more often weekly, starting from a few days after planting to control cowpea insect pests. This may require as many as 6 to 8 times and above before harvest (Omongo et al., 1977). Consequently, any control method that tends to reduce the number of insecticide application and still produce the desired yield should be encouraged / adopted.

This study aims at minimising the number of times insecticides are applied, in the control of insect pests and yield of cowpea in two locations in Delta State during the late cropping season.

\section{Materials and Methods}

The trials took place during the late planting season at Asaba and Abraka (two locations about 135 kilometres apart). The study was conducted in Asaba in the Teaching and Research Farms of the Agronomy department while at Abraka, on a plot of land, adjacent to Campus 2, Delta State University. For Asaba, the global position system (GPS) is $06^{0} 4^{1} ; 06^{0} 49^{\mathrm{E}}$ and the weather data for 2005 were, annual mean rainfall (mm) 163.70, annual relative humidity 80.41 and annual mean temperature $28.81^{\circ \mathrm{C}}$. For Abraka, the location statistics are GPS- $05^{0} 47^{1} \mathrm{~N}$, annual mean rainfall 232.46; annual relative humidity 83.00 and annual temperature $30.51^{0 \mathrm{C}}$. The experimental beds were prepared manually in both locations with hoes and shovels. Each plot measured $5 \times 3 \mathrm{~m}$ and in between plots was $1.5 \mathrm{~m}$. The seeds - Ife brown (obtained from the International Institute of Tropical Agriculture Ibadan, Nigeria) were planted. Three seeds per hole were planted, at spacing of $60 \times 30 \mathrm{~cm}$ (Remison, 1978e). Planting took place on $17^{\text {th }}$ September, 2005 at Asaba and in Abraka on $29^{\text {th }}$ September, 2005. Seeds that failed to sprout were replaced four days after planting. Thinning to 2 per stand occurred 10 days after plant emergence. Each experimental plot consisted of 6 rows of 36 plants. The experiments consisted of 4 treatments and 3 replicates, organised into a complete randomised block design. The treatments were:

(i) Calendar spray at 7 days' intervals, CA.S7 (carried out 5 times)

(ii) Calendar spray at 10 days' intervals, CA.S10 (carried out 4 times)

(iii) Monitored spray, carried out only when insect pest infestation/damage reached the action threshold (AT)

(iv) Control - no chemical application

The AT for the study insects was arrived at, following the method reported by Afun et al. (1991). Mean scores of the insect pests observed in the field were calculated and served as the AT. The AT for A.craccivora, M.sjostedti and pod sucking bugs were 3,3 and 2 respectively. Damage of 40 percent and above, of flowers, was used as the AT for M.vitrata.

Chemical application commenced 25 days after planting (Afun et al., 1991).

\subsection{Insect Observations and Data Collection}

The effect of chemical treatment on 4 major insect pests and grain yield of cowpea was determined. 
Aphis craccivora: This was determined weekly from the two middle rows of each plot between 8 and 10 a.m. when the plants were 26 days after planting (DAP). Twenty cowpea stands, tagged randomly were carefully inspected for aphid colony and the size rated visually (Table 1). The mean for the 20 stands was then calculated and recorded. Six observations were made.

Megalurothrips sjostedti: Assessment of thrips damage to cowpea in the field was done at 30 DAP. Damage symptoms such as browning/drying of stipules, leaf or flower buds and abscission were used to visually score 20 stands randomly tagged in the 2 middle rows of each plot. The rating was carried out in the morning between 8 and 10 a.m. and the mean score for the 20 stands was calculated and recorded. Four observations were made at the intervals of 6 days.

Maruca vitrata: This was done by counting. Twenty flowers randomly chosen from the 2 outer rows were opened each, between 3 and 5 p.m. and each was inspected on the spot for Maruca damage. Holes on the flowers and larval presence were the damage index by Maruca. Population of flower bud thrips in each flower was also counted.

Five observations were made at the intervals of five days. The mean for the 20 flowers was then calculated and recorded.

Pod sucking bugs (PSBs): The number of PSBs that rested on cowpea in the two middle rows of each plot was recorded in the morning ( 8 to 10 a.m.) at 45 DAP. Pod sucking bugs have similar damage and thus all were counted together. Four observations were made at 7 days' intervals.

Grain yield: This was done at the age of 65 to 70 days when the pods were matured. They were harvested and kept in polythene bags labelled according to treatments. The pods were dried by means of sunlight for 7 days and then shelled with hands. Grains in each treatment were weighed with triple beam balance (Haus model) and the weight recorded. Mean of replicates for each treatment was then calculated. The yield was extrapolated to kilogram per hectare.

\subsection{Yield Related Components}

Number of pods per plant: This was assessed in the field from the 2 middle rows of each plot when the pods were 60 DAP. Two sticks were used to mark out 1 metre long distance in the 2 central cowpea rows. All the pods and their stands that fell within this distance were then counted. The number of pods was divided by the number of stands:

$$
\text { Number of pods } / \text { plant }=\frac{\text { No. of pods }}{\text { No. of plant stands }}
$$

Pod load (PL) and Pod damage (PD): Assessment was done at 60 DAP. From the 2 middle rows of each plot, the PL was rated visually on a scale of 1-9 points (Table 3). For the PD, holes and frass on pods and sticking of pods were the Maruca damage index.

Pod evaluation index (Ipe): This was determined by the formula - PL x (9-PD),

where PL is pod load and PD, pod damage (Jackai et al., 1988).

Pod length and seed damage: At 65 DAP, matured pods were harvested from the 2 central rows of the plots into black polythene bags. The pods were then dried under sunlight for 1 week. With a flexible thread, each pod was measured to determine its length. Each was carefully opened with hand, and the number of seeds per pod was counted. The seeds in each pod were classified into aborted seeds per pod, wrinkled seeds/pod and seeds with feeding lesions per pod.

The data for insect observation, yield and yield related components were subjected to analysis of variance (ANOVA) and significant means separated by Fisher's Least Significant Difference Test (LSD), at 5\% level of significance.

\section{Results}

When compared with control, the major insect pests (except PSBs) were significantly reduced in the chemically protected plots at Asaba (Table 4). There was no significant difference with respect to PSBs among the insecticide protected plots and control. At Abraka, in the same season, A. craccivora, flower bud thrips and $M$. vitrata were significantly reduced in all the insecticide protected plots when compared to control. Conversely, M. sjostedti and PSBs were statistically similar in the treatments and when compared with control (Table 5).

Comparing the two locations, during the late cropping season of cowpea, the population of A. craccivora was significantly $(\mathrm{P}<0.05)$ higher at Abraka than Asaba. With M. sjostedti damage, flower bud thrip population, 
Maruca damage and coreid bugs, their incidence were significantly $(\mathrm{P}<0.05)$ more pronounced at Asaba than Abraka location (Table 6).

Grain yield at Asaba (Table 7), during the late season was high. All the plots treated with insecticide produced grains that were significantly $(\mathrm{P}<0.05)$ higher than grains from control. The insecticide treated plots were statistically similar. On yield related components, 100 seed weight, pod length, aborted seeds/pod and wrinkled seeds/pod were not significantly different among the treatments. However, all other yield related components such as; number of pods/ plant, number of seeds/pod, pod load, pod damage and pod evaluation index showed significant differences among the treatments.

At Abraka (Table 8), in the same season, grain yield was significantly $(\mathrm{P}<0.05)$ higher in all the chemically treated plots when compared with control. Grain yield in the insecticide treated plots were not significantly different; yields were highest in CA.S10 $\left(1,814.00 \mathrm{~kg} \mathrm{ha}^{-1}\right)$ and least was in MOS $\left(1,577.00 \mathrm{~kg} \mathrm{ha}^{-1}\right)$. Yield related components manifested variations in values, as effect of chemical spray in the different treatments. Number of pods/plant, pod load, pod damage, pod evaluation index and wrinkled seeds/pod were significantly different among the treatments. Conversely, 100 seed weight, pod length, aborted seeds/pod and seeds with feeding lesions had values that were not significantly different among the treatments.

Effect of location on grain yield and yield related components under cypermethrin application in the late season in the study areas is presented in Table 9. Dry grain yields were significantly $(\mathrm{P}<0.05)$ higher at Abraka $\left(1,400.60 \mathrm{~kg} / \mathrm{ha}^{-1}\right)$ than Asaba $\left(714.40 \mathrm{~kg} / \mathrm{ha}^{-1}\right)$. There was no significant difference between the locations with respect to one hundred seeds weight, so also were pod load, pod damage, pod evaluation index, wrinkled seeds per pod and seeds with feeding lesions. However, seeds from Asaba weighed slightly more than the seeds from Abraka. Pod production was more and significantly $(\mathrm{P}<0.05)$ higher in Abraka than Asaba. Similarly, pod length were significantly higher in values at Abraka than Asaba. Conversely, number of seeds per pod and aborted seeds per pod, were significantly higher in Asaba than Abraka location.

\section{Discussion}

During the late cropping season, all the major insect pests were encountered in the study areas - an observation which tallied with the reports of Jackai et al. (1988) and Singh and Jackai (1985) that the major insect pests of cowpea occur wherever the crop is cultivated in Nigeria. The occurrence and distribution of insect species in this study in the two locations followed different trends. The insect species except $A$. craccivora were significantly more at Asaba compared to Abraka. Asaba campus, formerly College of Agriculture, inconsistently cultivated cowpea for consumption in some years back and this could have been a major factor which possibly contributed to the abundant occurrence of cowpea pests before the present study was carried out. Abraka on the other hand, had never been known to cultivate cowpea. Other possible factors for the variation of insect species in the two agro-ecological zones were climatic and environmental changes. Asaba which is located in the drier Northern part of the state had the mean annual rainfall, temperature and relative humidity of $163.70 \mathrm{~mm}, 28.81^{\circ} \mathrm{C}$ and $80.4 \%$ respectively in 2005. Abraka, which is close to the Niger Delta region, the annual mean rainfall in the same year was $232.46 \mathrm{~mm}$ and annual mean temperature was $30.51^{\circ} \mathrm{C}$. These could have influenced occurrence and distribution of insect species in locations that are widely apart (about 135 kilometres apart) in Delta State. Tobih (2007) reported higher yam tuber damage by beetles at Ugbolu than Anwai. This study has made similar observations between Asaba and Abraka.

Cypermethrin (conventional chemical) effectively controlled the major insect pests in the various treatments at both locations, to conform with reports of earlier cowpea researchers (Jackai \& Singh, 1986; Jackai, 1993). On grain yield, both locations recorded high yield, 714.40 $\mathrm{kgha}^{-1}$ at Asaba and 1,400.60 $\mathrm{kgha}^{-1}$ at Abraka. The values for grain yield in the study areas compared favourably with yield from some other cowpea growing areas of Nigeria such as Bauchi (Degri \& Hadi, 2000) Kamboinse, Badeggi, Mokwa, Samaru, Kano and Ilora, (IITA, Annual Report, 1986) and Calabar (Emosairue et al., 1994).

The significantly higher grain yield at Abraka (compared to Asaba) may be attributed to less insect damage to cowpea in this region and probably too, soil and favourable climatic factors which prevailed during the study period. Yield differences due to locational effects have been reported earlier for some other crops such as cassava (Akparobi et al., 2002), maize (Agbogidi, 2006) and yam (Tobih, 2007).

Though cypermethrin effectively controlled the major insect pests of cowpea in the two agro-ecological zones and grain yield was high at both locations, this chemical, like most other conventional chemicals has adverse side effect such as environmental pollution, toxicity to mammals, users and consumers (Alabi et al., 2003). From Uganda, it is reported that commercial farmers in this country spray their farms from 8 to 10 times during the growing season (Omongo et al., 1997). However, if this is the practice in Uganda, what about the cost of 
chemicals or are these chemicals supplied to farmers free of charge? Certainly, the high number of chemical application would increase the cost of production and chemical residues in cowpea grains which ultimately would not be healthy for human consumption. Excessive and unwise use of chemicals have ultimately, serious environmental consequences as noted above. The present study which employed 5 or 4 times spray before harvest or monitored insect infestation/damage before spraying has advantages of reducing the number of chemical sprays and still produce the desired grain yield, and environmental pollution is minimal. Findings in this study support the report of Afun et al. (1991) who stated that significant differences did not exist in calendar spray(CA.S7 and CA.S10) and monitored sprays (MOS) in terms of insect number and grain yield.

The present study provides preliminary reports on the following:

(i) That environmental pollution is reduced, if farmers spray their farms 4 times (at 7 days' intervals or 5 times (at 10 days' intervals) before harvest or monitored insect damage before spraying; grain yield is appreciable.

(ii) Grain yield is much higher (highly significant) at Abraka than Asaba.

(iii) The study areas are suitable for large scale cowpea production.

\section{References}

Adamu, R. S., Onu, I., Dike, M. C., \& Ogunloma, M. O. (2007). Effect of sorghum (Sorghum bicolor (L) Moench) variety on severity of headbug (Eurystylus oldi pop) damage. Nigerian Journal of Entomology, 24, 68-75.

Afun, J. V. K., Jackai, L. E. N., \& Hodgson, C. J. (1991). Calendar and monitored insecticide application for the control of cowpea pests. Crop Protection, 10, 363-370. http://dx.doi.org/10.1016/S0261-2194(06)80025-6

Agbaje, G. O., Adegbite, A. A. Akinlosotu, T. A., \& Soyinka, S. A. (2002) Performance of new hybrid yan (Discorea rotundata Poir) varieties under different cropping systems. African Journal of Root and Tuber Crop, 5(1), 8-11.

Agbogidi, M. O. (2006). Effects of soil contamination with crude oil on the growth and yield of maize (Zea mays L) in Delta State. Ph.D thesis, Delta State University, Abraka

Akparobi,S. O., Togun, A. O., Ekanayake, I. J., \& Dris, R. (2002). Effects of low temperatures on dry matter partitioning and yield of cassava clones. Tropical Science, 42(1), 22-29.

Alabi, O. Y., Odebiyi, J. A., \& Jackai, L. E. N. (2003). Field evaluation of cowpea cultivars (Vigna unguiculata (L) Walp.) for resistance to flower bud thrips (Megalurothrips sjostedti Trybom) Thysanoptera: Thripidae. International Journal of Pest Management, 49(4), 287-291. http://dx.doi.org/10.1080/0967087031000123706

Aykroyd, W. R., \& Doughty, J. (1982). Legumes in Human Nutrition. FAO. Nutrition Studies 19, FAO, Rome.

Degri, M. M., \& Hadi, H. M. (2000). Field evaluation and economies of some insecticides against the major insect pests of cowpea (Vigna unguiculata (WALP) in Bauchi, Nigeria. ESN Occasional Publication, 32, 113-118.

Duke J. A. (1981). Vigna unguiculata (L) Walp. Spp unguiculata In: legumes of world economic importance p. 303-305. Plenum Press, New York, USA.

Egho, E. O. (2010). Studies on the control of major insect pests and yield of cowpea (Vigna unguiculata (L) Walp under calendar and monitored application of synthetic chemical in Abraka, southern Nigeria. Archives of Applied Science Research, 2010, 2(4)c, 224-234.

Egho, E. O. (2011). Management of major field insect pests and yield of cowpea (Vigna unguiculata (L) Walp) under calendar and monitored application of synthetic chemicals in Asaba, Southern Nigeria. American Journal of Scientific and Industrial Research (AJSIR). http://dx.doi.org/10.5251/ajsir.2011.2.4.592.602

Emosairue, S. O., Eze, D. E., \& Okore, I. K. (1994). Timing of insecticidal application in Vigna unguiculata (L) Walp, CV.IT84S-2246-4 and its potential as late season crop in the Calabar area. Journal of Applied Chemistry and Agricultural Resource, 1(1), 6-11.

Emosairue, S.O., Nwofia, G. E., \& Umuetok, S. B. A. (2004). Observation on the Insect complex associated with cowpea (Vigna unguiculata (L.) Walp) in Umudike, South-eastern. Nigeria. J. Sustain. Agric. Environ., 6(1), $38-43$.

FOS. (1995). Annual Abstract of statistics, Lagos, Nigeria.

IITA. (1986). Annual report for 1985, Grain Legume Improvement Program, Ibadan, Nigeria. 
Ikeorgu, J. E. G., \& Igwilo, H. N. (2002). Effect of mulching and staking on yam growth under irrigation during the dry season in Umudike, South Eastern Nigeria. Journal of Sustainable Agric and Environment, 4(1), 129-132.

Jackai, L. E. N., Goudou, C., Asiwe, J. A. N., \& Tayo, B. O. (2001). Integrated control of the cowpea aphid, using seed dressing and varietal resistance. Samaru J. Agric Res., 17, 13-23.

Jackai, L. E. N., Roberts, J. M. F., \& Singh, S. R. (1988). Cowpea seed treatment with carbosulfan potential for control of seedling pests. Crop Protection, 7, 384-390. http://dx.doi.org/10.1016/0261-2194(88)90007-5

Jackai, L. E. N. (1983). Efficacy of Insecticide Application at different times of day against the legume pod borer Maruca vitrata (FAB) (Lepidoptera, Pyralidae, on cowpea in Nigeria. Protection Ecology, 5, 245-251.

Jackai, L. E. N. (1993). The use of neem in controlling cowpea pests. IITA Research, 7, 5-11.

Jackai, L. E. N., \& Daoust, R. A. (1986). Insect pests of cowpeas. Annual Review of Entomology, 31, 95- 119.

Jackai, L. E. N., \& Singh, S. R. (1986). New foloiar insecticides for the control of cowpea pests. In: Proc. 1986 Br. Crop Protection Conf-Pests diseases. 761-768.

Job, T. A., Maner, J. H. \& Buitrago, J. (1983). Nigerian journal of Nutritional Sciences, 4(1), 29-34.

Okigbo, B. N. (1978). Grain legumes in the agriculture of the tropics. In Pests of Grain legumes Ecology and control (Edited by Singh S.R. Van emden H.E. and Taylor T.A) Academic Press, Inc., New York.

Okonman, L. U., \& Emoseurue, S. O. (2005). Effect of Interactions of low growing crops and mineral fertilizer levels on the yield performance of maize. Plant Protection Research Journal, 5(10), 34-45.

Olaniyan, A. A., Kolade, J. A., Ojeifo, I. M., \& Jolaoso, M. A. (2001). Effect of Alley-Cropping with Leucaena leucocephala on the Growth of budded citrus seeding in the nursery. Nigerian Journal of Ecology, 3, 60-64

Omoloye, A. A., Joda, A. O., \& Tobah, F. O. (2000). Effects of planting dates and intra-row spacing on field infestation and damage by Hemipteran sucking bugs on soyabean in Ibadan, Southwest Nigeria. Plant Sciences Research Communications, 1(1), 39-44.

Omongo, C. A., Adipala, E., Ogenga Latigo, M. W., \& Kyamanywa, S. (1997). Insecticide application to reduce pest infestation and damage on cowpea in Uganda. Afri. Plant Prot., 4(2), 91-100.

Rachie, K. O. (1985). Introduction. P. xxi xxviii. In: S.R. Singh and K.O. Rachie (eds). Cowpea research, production and utilization. Wiley New York.

Remison, S. U. (1978e). Cowpea agronomy works at National Cereals Research Institute. Paper presented at the 1 st National meeting. On development of package. Recommendations for legume crops at N.C.R.I, Ibadan, 7-8 February.

Singh, S. R., \& Allen, D. J. (1980). Pests, diseases, resistance and protection in cowpea. In summerfield, R.J., and Bunting, A.H., eds., Advances in legume Science. London, UK, Her Majesty's Stationery office, 419-443.

Singh, S. R., \& Jackai, L. E. N. (1985). Insect pests of cowpeas in Africa: their life cycle, economic importance and potential for control. Pages 217-231 in cowpea research production and utilization, edited by S.R. Singh and K.O. Rachie. John Wiley and Sons N.Y.

Stern V. M. (1973). Economic threshholds. A. Rev. Entomol., 18, 259-280. http://dx.doi.org/10.1146/annurev.en.18.010173.001355

Suh, J. B., Jackai, L. E. N., \& Hammond, W. N. O. (1986). Observations on pod sucking bug populations on cowpea at Mokwa, Nigeria. Tropical Grain legume Bulletin, 33, 17-19.

Taylor, T. A. (1964). The field pest problems on cowpea. (Vigna sinensis L.) in Southern Nigeria, Grower Producer, 3(2), 15-19.

Tobih, F. O. (2007). Control of yam beetle Heteroligus meles Bilb (Coleoptera. Dynastidae) in the rain forest zone of the upper Niger Delta, Nigeria. Ph.D thesis, Delta State University, Abraka, P. 49.

Tobih, F. O. (2011). Effect of planting dates on yield and insect pests associated with guinea corn (Sorghum bicolor $(L)$ Moench in Oshimili Area Delta State, Nigeria. Biological and Environmental Sciences Journal for the Topics, 8(2), 7-10.

Tobih, F. O., Okonmah, L. U., Omoloye, A. A. (2011). Assessment of Yield potentials and damage of Yams in Uncontrolled Upland Yam monocrop system with varying planning dates in Oshimili Area of Delta State, Nigeria. International Journal of Agric Science, 1(3), 178-184. 
Table 1. Scale for rating aphid infestation on cowpea

Source: Litsinger et al. (1977)

\begin{tabular}{ccc}
\hline Rating & Number of aphids & Appearance \\
\hline 0 & 0 & no infestation \\
1 & $1-4$ & a few individual aphids \\
3 & $5-20$ & a few isolated colonies \\
5 & $21-100$ & several small colonies \\
7 & $101-500$ & large isolated colonies \\
9 & $>500$ & large continuous colonies \\
\hline
\end{tabular}

Table 2. Scale for rating flower bud thrips infestation on cowpea

\begin{tabular}{cc}
\hline Rating & Appearance \\
\hline 1 & no browning/drying (i.e scaling) of stipules, leaf or flower buds; no bud abscission \\
5 & initiation of browning of stipules, leaf or flower buds; no bud abscission \\
7 & distinct browning/drying of stipules and leaf or flower buds; some bud abscission \\
9 & serious bud abscission accompanied by browning/drying of stipules and buds; non \\
elongation of peduncles
\end{tabular}

After Jackai and Singh (1988)

Table 3. Scale for rating Maruca vitrata damage to cowpea

\begin{tabular}{cccc}
\hline \multirow{2}{*}{ Rating } & Pod load (PL) & \multicolumn{2}{c}{ Pod damage (PD) } \\
Degree of podding & Rating & $\%$ \\
\hline 1 & most $(<60 \%$ peduncles bare (i.e. no pods) & 1 & $0-10$ \\
3 & $31-50 \%$ peduncles bare & 2 & $11-20$ \\
& & 3 & $21-30$ \\
& & 4 & $31-40$ \\
& & 5 & $41-50$ \\
7 & & 6 & $51-60$ \\
& & 7 & $61-70$ \\
9 & Up to $15 \%$ peduncles bare & 8 & $71-80$ \\
& & 9 & $81-100$ \\
\hline
\end{tabular}

After Jackai and Singh (1988)

Table 4. Effect of cypermethrin on the major insect pests of cowpea during the late cropping season at Asaba Egho (2011)

\begin{tabular}{cccccc}
\hline Treatments & $\begin{array}{c}\text { Aphis } \\
\text { craccivora } \\
\text { (rating)** }\end{array}$ & $\begin{array}{c}\text { Megalurothrips } \\
\text { sjostedti } \\
\text { (rating) }\end{array}$ & $\begin{array}{c}\text { Flower bud } \\
\text { thrips* } \\
\text { (actual counting) }\end{array}$ & $\begin{array}{c}\text { Maruca vitrata* } \\
\text { (actual counting) }\end{array}$ & $\begin{array}{c}\text { PSB** (actual } \\
\text { counting) }\end{array}$ \\
\hline CONTROL & 1.22 & 2.17 & 8.39 & 0.18 & 3.00 \\
CA.S7 & 0.00 & 1.33 & 3.61 & 0.08 & 3.33 \\
CA.S10 & 0.44 & 1.33 & 3.92 & 0.08 & 3.78 \\
MO.S & 0.44 & 1.33 & 4.76 & 0.10 & 2.22 \\
LSD(0.05) & 0.78 & 0.53 & 1.47 & 0.08 & NS \\
\hline
\end{tabular}

N.S - Not significant, CA.S7 - Calendar spray at 7 days' intervals

CA.S10 - Calendar spray at 10 days' intervals, MOS - Monitored spray

* Means of 20 flowers ** Number per 2-middle rows 
Table 5. Effect of cypermethrin on the major insect pests of cowpea in the late cropping season at Abraka Egho (2010)

\begin{tabular}{cccccc}
\hline Treatments & $\begin{array}{c}\text { Aphis craccivora } \\
\text { (rating)** }\end{array}$ & $\begin{array}{c}\text { Megalurothrips } \\
\text { sjostedti } \\
\text { (rating) }\end{array}$ & $\begin{array}{c}\text { Flower bud } \\
\text { thrips* } \\
\text { (actual counting) }\end{array}$ & $\begin{array}{c}\text { Maruca } \\
\text { vitrata* } \\
\text { (actual } \\
\text { counting) }\end{array}$ & $\begin{array}{c}\text { PSB** } \\
\text { (actual counting) }\end{array}$ \\
\hline CONTROL & 1.89 & 1.50 & 3.33 & 0.07 & 0.02 \\
CA.S7 & 1.22 & 1.00 & 1.85 & 0.02 & 0.04 \\
CA.S10 & 1.00 & 1.00 & 2.25 & 0.02 & .0 .02 \\
MO.S & 1.11 & 1.00 & 2.83 & 0.04 & 0.04 \\
LSD(0.05) & 0.42 & NS & 1.37 & 0.05 & NS \\
\hline
\end{tabular}

N.S - Not significant, CA.S7 - Calendar spray at 7 days' intervals

CA.S10 - Calendar spray at 10 days' intervals, MOS - Monitored spray

* Means of 20 flowers ** Number per 2-middle rows

Table 6. Effect of location on the major insect pests of cowpea under the application of cypermethrin in late cropping season at Asaba and Abraka

\begin{tabular}{cccccc}
\hline Location & $\begin{array}{c}\text { Aphis craccivora } \\
\text { (rating) }\end{array}$ & $\begin{array}{c}\text { Megalurothrips } \\
\text { sjostedti } \\
\text { (rating) }\end{array}$ & $\begin{array}{c}\text { Flower bud } \\
\text { thrips* } \\
\text { (actual counting) }\end{array}$ & $\begin{array}{c}\text { Maruca vitrata* } \\
\text { (actual counting) }\end{array}$ & $\begin{array}{c}\text { PSB** }^{* *} \\
\text { (actual counting) }\end{array}$ \\
\hline Asaba Late & 0.53 & 1.54 & 5.17 & 0.11 & 3.08 \\
Abraka Late & 1.31 & 1.13 & 0.05 & 0.05 & 0.03 \\
LSD (0.05) & 0.31 & 0.23 & 0.45 & 0.05 & 0.55 \\
\hline
\end{tabular}

* Means of 20 flowers ** Number per 2 middle rows

NS-Not significant

Table 7. Effect of cypermethrin on grain yield and yield related components from cowpea in the late season at Asaba

Source: Egho (2011)

\begin{tabular}{|c|c|c|c|c|c|c|c|c|c|c|c|}
\hline Treatments & $\begin{array}{c}\text { Dry } \\
\text { Grain } \\
\text { yield } \\
(\mathrm{kg} \\
\left.\mathrm{ha}^{-1}\right)\end{array}$ & $\begin{array}{c}100 \\
\text { seeds } \\
\mathrm{wt}(\mathrm{g})\end{array}$ & $\begin{array}{c}\text { Number } \\
\text { of pods/ } \\
\text { plant } \\
\text { (approx) }\end{array}$ & $\begin{array}{l}\text { Pod } \\
\text { length } \\
(\mathrm{cm})\end{array}$ & $\begin{array}{c}\text { Number } \\
\text { of } \\
\text { seeds/pod }\end{array}$ & $\begin{array}{l}\text { Pod } \\
\text { load }\end{array}$ & $\begin{array}{c}\text { Pod } \\
\text { damage }\end{array}$ & $\begin{array}{c}\text { Pod } \\
\text { evaluation } \\
\text { index }\end{array}$ & $\begin{array}{c}\text { Aborted } \\
\text { seeds/pod }\end{array}$ & $\begin{array}{l}\text { Wrinkled } \\
\text { seeds/pod }\end{array}$ & $\begin{array}{l}\text { Seeds } \\
\text { with } \\
\text { feeding } \\
\text { lesions }\end{array}$ \\
\hline CONTROL & 238.40 & 16.10 & 4.93 & 12.59 & 11.78 & 4.33 & 6.67 & 19.00 & 2.50 & 2.43 & 0.05 \\
\hline CA.S7 & 843.90 & 15.20 & 8.61 & 12.33 & 12.62 & 8.33 & 2.33 & 60.00 & 2.67 & 0.78 & 2.25 \\
\hline CA.S10 & 940.20 & 16.07 & 10.88 & 12.54 & 12.90 & 9.00 & 2.00 & 63.00 & 2.80 & 1.18 & 0.08 \\
\hline MO.S & 835.00 & 15.57 & 11.65 & 12.71 & 13.25 & 9.00 & 2.00 & 63.00 & 2.40 & 0.65 & 0.02 \\
\hline $\operatorname{LSD}(0.05)$ & 172.00 & NS & 3.58 & NS & 1.45 & 2.40 & 0.74 & 22.23 & NS & NS & NS \\
\hline
\end{tabular}

N.S - Not significant, CA.S7 - Calendar spray at 7 days' intervals, CA.S10 - Calendar spray at 10 days' intervals, MOS - Monitored spray 
Table 8. Effect of cypermethrin on grain yield and yield related components from cowpea in the late season at Abraka

Source: Egho (2010)

\begin{tabular}{|c|c|c|c|c|c|c|c|c|c|c|c|}
\hline Treatments & $\begin{array}{c}\text { Dry } \\
\text { Grain } \\
\text { yield } \\
(\mathrm{kg} \\
\left.\mathrm{ha}^{-1}\right)\end{array}$ & $\begin{array}{c}100 \\
\text { seeds } \\
\operatorname{wt}(\mathrm{g})\end{array}$ & $\begin{array}{c}\text { Number } \\
\text { of pods/ } \\
\text { plant } \\
\text { (approx) }\end{array}$ & $\begin{array}{l}\text { Pod } \\
\text { length } \\
(\mathrm{cm})\end{array}$ & $\begin{array}{l}\text { Number } \\
\text { of } \\
\text { seeds/pod }\end{array}$ & $\begin{array}{l}\text { Pod } \\
\text { load }\end{array}$ & $\begin{array}{c}\text { Pod } \\
\text { damage }\end{array}$ & $\begin{array}{c}\text { Pod } \\
\text { evaluation } \\
\text { index }\end{array}$ & $\begin{array}{c}\text { Aborted } \\
\text { seeds/pod }\end{array}$ & $\begin{array}{l}\text { Wrinkled } \\
\text { seeds/pod }\end{array}$ & $\begin{array}{l}\text { Seeds } \\
\text { with } \\
\text { feeding } \\
\text { lesions }\end{array}$ \\
\hline CONTROL & 424.10 & 12.37 & 11.82 & 12.94 & 10.37 & 3.00 & 7.33 & 7.67 & 0.37 & 1.88 & 0.10 \\
\hline CA.S7 & 1787.40 & 15.60 & 11.67 & 12.80 & 11.02 & 8.67 & 2.00 & 60.67 & 0.43 & 0.70 & 0.00 \\
\hline CA.S10 & 1814.00 & 15.63 & 9.09 & 13.01 & 11.28 & 9.00 & 2.00 & 63.00 & 0.82 & 0.48 & 0.00 \\
\hline MO.S & 1577.00 & 16.23 & 13.52 & 13.46 & 11.52 & 7.67 & 4.00 & 38.00 & 0.35 & 0.85 & 0.02 \\
\hline $\operatorname{LSD}(0.05)$ & 963.15 & NS & 4.34 & NS & NS & 2.40 & 2.08 & 13.33 & NS & 0.87 & NS \\
\hline
\end{tabular}

N.S - Not significant, CA.S7 - Calendar spray at 7 days' intervals, CA.S10 - Calendar spray at 10 days' intervals, MOS - Monitored spray

Table 9. The effect of location on cowpea yield and yield related components under the application of synthetic insecticides at Asaba and Abraka in the late season

\begin{tabular}{cccccccccccc}
\hline Season & $\begin{array}{c}\text { Dry } \\
\text { Grain } \\
\text { yield } \\
(\mathrm{kg} \\
\left.\mathrm{ha}^{-1}\right)\end{array}$ & $\begin{array}{c}100 \\
\text { seeds } \\
\mathrm{wt}(\mathrm{g})\end{array}$ & $\begin{array}{c}\text { Number } \\
\text { of pods/ } \\
\text { plant } \\
(\text { approx })\end{array}$ & $\begin{array}{c}\text { Pod } \\
\text { load } \\
(\mathrm{cm})\end{array}$ & $\begin{array}{c}\text { Pod } \\
\text { length } \\
(\mathrm{cm})\end{array}$ & $\begin{array}{c}\text { Pod } \\
\text { damage }\end{array}$ & $\begin{array}{c}\text { Pod } \\
\text { evaluation } \\
\text { index }\end{array}$ & $\begin{array}{c}\text { Number } \\
\text { of seeds } \\
\text { per pod }\end{array}$ & $\begin{array}{c}\text { Aborted } \\
\text { seeds/pod }\end{array}$ & $\begin{array}{c}\text { Wrinkled } \\
\text { seeds/pod }\end{array}$ & $\begin{array}{c}\text { Seeds } \\
\text { with } \\
\text { feeding } \\
\text { lesions }\end{array}$ \\
\hline Asaba Late & 714.40 & 15.73 & 9.02 & 7.67 & 12.54 & 3.25 & 51.25 & 12.64 & 2.59 & 1.26 & 0.10 \\
Abraka Late & 1400.60 & 14.96 & 11.53 & 7.08 & 13.05 & 3.83 & 42.33 & 11.05 & 0.49 & 0.98 & 0.03 \\
LSD(0.05) & 336.46 & NS & 1.44 & NS & 0.44 & NS & NS & 0.62 & 0.72 & NS & NS \\
\hline
\end{tabular}

NS = Not significant 